\title{
Dos veces Julio. Sobre algunas memorias fotográficas del pasado reciente en la Argentina
}

Two times Julio. On some photographic memories of the recent past in Argentina

\section{NATALIA ForTUNY}

UNIVERSIDAD DE BUENOS AIRES / CONICET · nataliafortuny@gmail.com

Doctora en Ciencias Sociales por la Universidad de Buenos Aires e Investigadora del Conicet. Dirige y participa en diversos proyectos de investigación sobre fotografía y memoria. Publicó los libros Memorias fotográficas. Imagen y dictadura en la fotografía argentina contemporánea (La Luminosa, 2014) e Instantáneas de la memoria: fotografía y dictadura en Argentina y América Latina (Libraria, 2013, coeditado con Jordana Blejmar y Luis Ignacio García). Y, en poesía, los libros Hueso (Ediciones En Danza, 2007) y La construcción (Gog y Magog, 2010). También ha sido curadora de diversas muestras de fotografía y ha exhibido sus propios trabajos fotográficos en galerías y cubiertas de libros bajo el seudónimo de Nat Oliva.

Resumen: El punto de partida de este artículo es una foto de Julio López, ex detenido-desaparecido de la pasada dictadura argentina y vuelto a desaparecer en 2006 tras dar testimonio en el juicio que condenó al represor Miguel Etchecolatz a prisión perpetua. Una foto de López ya vista será ahora reinsertada en otro contexto, duplicada para ser dada nuevamente a la mirada. Desde ella se desplegarán las singularidades de algunas otros artefactos visuales entendidos como memorias fotográficas de la historia reciente argentina ligada a la pasada dictadura. Fotos que en sus mismos procedimientos de construcción de lo pasado se van conformando como artefactos de memoria, tensando particularmente las cuestiones del paisaje y de la figura del desaparecido.

Palabras Clave: Fotografía argentina, memorias sociales, desaparecidos.

\begin{abstract}
The starting point of this article is a photo of Julio López, ex detained-disappeared in Argentina's last dictatorship. López disappeared again in 2006, after giving testimony at the trial that convicted repressor Miguel Etchecolatz to life imprisonment. One iconic photo of Lopez will now be reinserted in another context, projected onto a river. From this, the peculiarities of some other photographic memories of Argentina's recent history will be displayed. Specially, as they are visual artifacts of memory that tense the question of the landscape and the forced disappearance.
\end{abstract}

Key Words: Photography, Social Memories, Desaparecidos. 
Natalia Fortuny. Dos veces Julio...

Este escrito se entreteje alrededor de una foto doble de Jorge Julio López. Una foto ya vista y ahora reinsertada en otro contexto, duplicada para ser dada nuevamente a la mirada.

Desde ella se desplegarán las singularidades de algunas otros artefactos visuales entendidos como memorias fotográficas de la historia argentina reciente, fundamentalmente de la pasada dictadura. Se trata de obras fotográficas que se vuelven memorias de una historia en común y que conjugan sus posibilidades tanto de ser huellas del mundo como de desplegar otros mundos: metafóricos, construidos. Así, la duplicidad propia del medio fotográfico - que es índice y metáfora- explota en estas fotos que, en sus mismos procedimientos de construcción de lo pasado, se van conformando como artefactos de memoria, siempre en relación y resonancia con los cambios históricos y las transformaciones de los climas sociales, políticos y culturales. ${ }^{1}$

La obra pertenece a la serie Apareciendo, de Gabriel Orge, que está aún en proceso. Fue comenzada precisamente como una intervención urbana al proyectar una foto de López sobre una esquina el jueves 18 de septiembre de 2014 al caer la noche en el barrio Cofico de la ciudad argentina de Córdoba ${ }^{2}$. Ese día se cumplían ocho años de la segunda desaparición de López, hecho del que ya se cumplieron nueve años.

Jorge Julio López fue dos veces desaparecido. La primera ocurrió durante la pasada dictadura argentina: el 27 de octubre de 1976 fue secuestrado de su casa en el barrio de Los Hornos, La Plata, y permaneció detenido-desaparecido durante casi tres años en Centros Clandestinos de Detención (CCD) a cargo del represor y ex director de investigaciones de la policía bonaerense, Miguel Osvaldo Etchecolatz $^{3}$. La segunda desaparición de López ocurrió el 18 de septiembre de 2006, a la edad de 80 años. Precisamente un día antes de la sentencia a Etchecolatz a cadena perpetua en cárcel común, en el marco del juicio en que López era a la vez testigo y querellante. Desde esta segunda desaparición y tras nueve años de investigación la causa López no tiene ningún imputado, ningún procesado y ningún detenido.

\footnotetext{
1 Trabajé algunas cuestiones mencionadas aquí en el libro Memorias fotográficas. Imagen y dictadura en la fotografía argentina contemporánea (La Luminosa, 2014). También disponible en

${ }^{2}$ Cuando la foto de López se proyectó en una pared del barrio Cofico no todos los transeúntes vieron a López sino que vacilaban en identificarlo. Algunos pensaron que era Domingo Faustino Sarmiento -un "prócer" de nuestro país- o incluso "un Gran Hermano que nos mira”, según cita el mismo Orge.

${ }^{3}$ El último gobierno militar abarcó sangrientos años de la historia reciente argentina: desde el 24 de marzo de 1976 al 10 de diciembre de 1983, aunque se constatan asesinatos y desapariciones previas a esos años. Esta dictadura, signada por la represión, el terror y la censura, planeó y acometió la desaparición forzada de 30.000 personas, que fueron secuestradas y torturadas en centros clandestinos de detención, y cuyos cuerpos -en su mayoría- no han sido recuperados y permanecen desaparecidos.
} 
La figura de López encarna el testigo que deja su vida en la tarea de dar testimonio. López tomó, como muchísimos otros en nuestro país, el riesgo de ser testigo y querellante, y con su desaparición se ha pretendido infundir terror en quienes participan en los juicios por delitos de lesa humanidad. Lejos de constituir solamente la posibilidad reparatoria de ser escuchado, el dar testimonio expone y coloca al sobreviviente en un lugar incómodo, muchas veces cuestionado incluso por el hecho mismo de haber sobrevivido. Según Ana Longoni (2007), volver de la desaparición aísla a los sobrevivientes en una (sobre) vida que muchas veces también los condena ${ }^{4}$.

\section{La proyección de la memoria}

Deudor principalmente de una fotografía de la serie Desapariciones de Helen Zout, el fotógrafo cordobés Gabriel Orge ganó en 2015 el Primer Premio Adquisición en la categoría Fotografía del Salón Nacional de Artes Visuales con la obra “Apareciendo a López en el río Ctalamochita”.

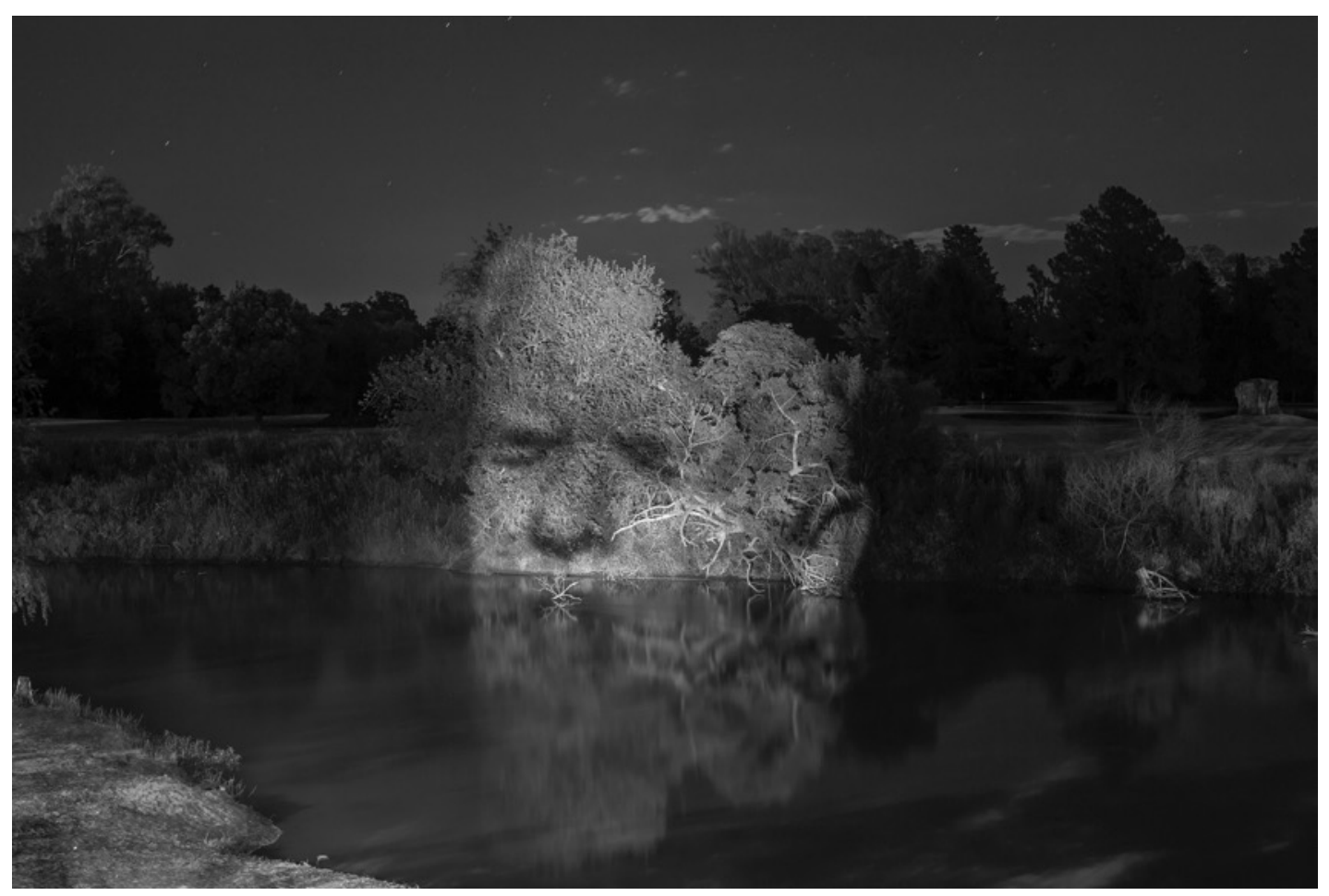

“Apareciendo a López en el río Ctalamochita” - Gabriel Orge, 2015, a partir de una foto de Helen Zout.

\footnotetext{
${ }^{4}$ Numerosas cuestiones se anudan en la figura del sobreviviente, a menudo estigmatizado como traidor o plausible delator (aún bajo tortura). Ana Longoni (2007) ha trabajado este tema en extenso a partir del análisis de un conjunto de obras literarias.
} 
Luego de intervenir la esquina conmemorando a López, y para continuar la serie, meses más tarde comenzó a proyectar la foto de López ya no en la ciudad sino en la naturaleza, en medio del paisaje serrano de su infancia, logrando la fotografía que aquí nos ocupa.

Por empezar, la imagen que Orge proyecta es una de las fotografías paradigmáticas de este testigo doblemente desaparecido. La foto de López con los ojos cerrados resuena en la memoria visual más reciente del reclamo por esta segunda desaparición ya que se ha podido ver en marchas, publicaciones y homenajes. Fue sacada por la fotógrafa platense Helen Zout en el año 2000, en el marco de una serie de entrevistas y retratos realizados a López. En el 2012, esta foto fue también premiada en el Salón Nacional de Artes Visuales y obtuvo el Gran Premio Adquisición, el mayor de los galardones de ese concurso.

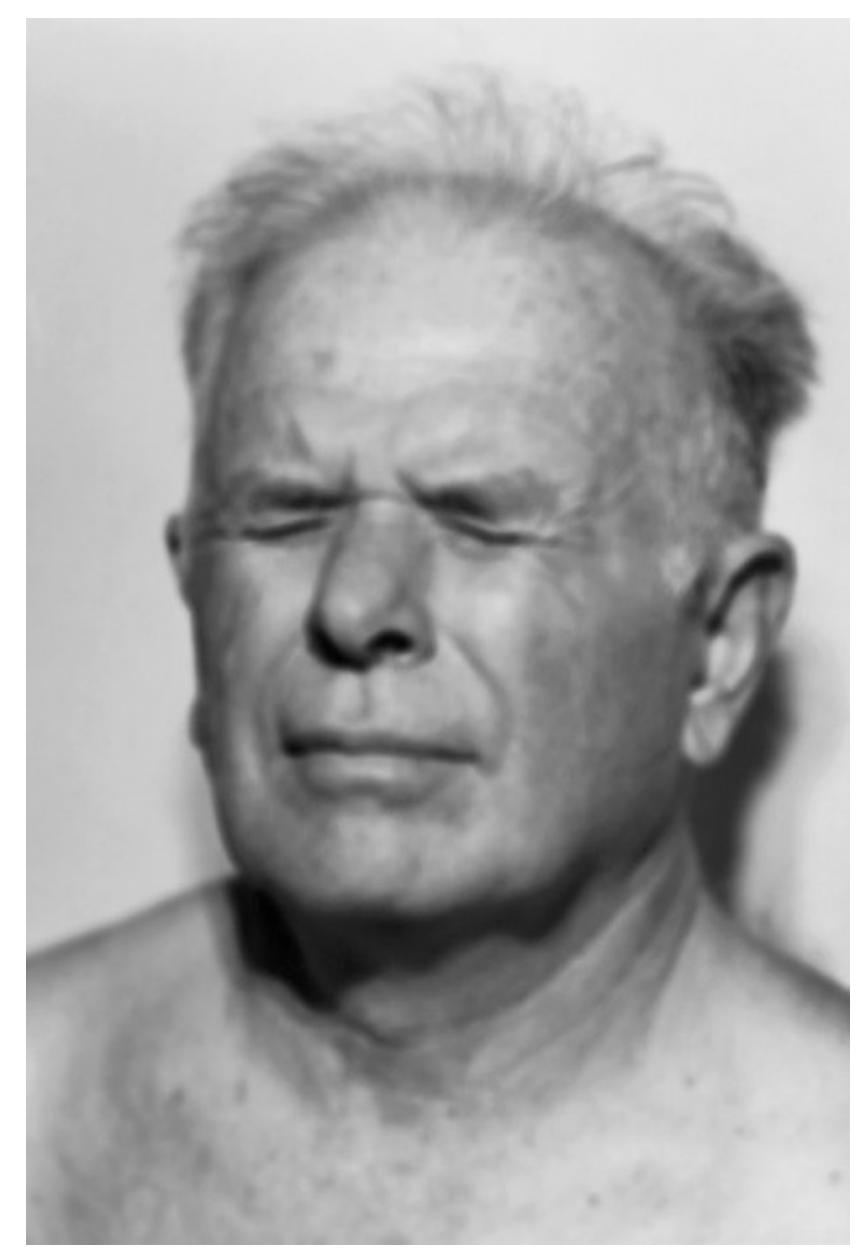

“Jorge Julio López, sobreviviente del centro clandestino Arana, La Plata, 2000” - Helen Zout, Desapariciones, 2011. 
Esta foto funciona como símbolo y emblema de la segunda desaparición forzada de López, esta vez en democracia-según Benjamin, el emblema es una de las formas de la alegoría ${ }^{5}$-.

En la muestra y libro Desapariciones Helen Zout hace un recorrido vasto y complejo, con mirada sobreviviente, acerca de las huellas del accionar represivo de la última dictadura. Así, recorriendo sus fotos aparecen las máquinas de matar como el Falcon o el avión de las Fuerzas Armadas ${ }^{6}$, los huesos recuperados por el Equipo Argentino de Antropólogos Forenses (EAAF) ${ }^{7}$, los escraches ${ }^{8}$ y también diversos retratos de sobrevivientes, ex detenidos desaparecidos de la última dictadura.

Es importante mencionar el punto de vista de las fotografías de Zout. La artista, compañera de militancia y amiga de muchos desaparecidos de La Plata, a menudo refiere el hecho de que los militares la fueron a buscar a su casa, pero ella no estaba en ese momento y logró esconderse por un tiempo para, de esa manera, salvarse. Este suceso, según sus palabras, la marcó profundamente y es por ello que se considera también ella misma una sobreviviente. Precisamente, en sus fotos se ve claramente esta perspectiva generacional y biográfica empática con el desaparecido y con el ex-detenido-desaparecido. Una perspectiva emparentada, en cuanto al acercamiento al objeto, por ejemplo con las fotos de Paula Luttringer, también sobreviviente y fotógrafa.

Zout ha afirmado que su "lugar es el lugar que hubiera tenido el desaparecido: la persona torturada, tirada al río. Cada cual hace su trabajo desde su lugar”. Y también que su mirada se distingue de la de otras generaciones o colectivos, por ejemplo, de las obras de hijos de desaparecidos como las fotos reconstruidas de Lucila Quieto, ya que tienen un acercamiento diferente. Entre las diversas estrategias visuales que despliegan los hijos en sus obras se destacan los montajes y la reutilización de las fotos de sus propios álbumes familiares ${ }^{9}$.

\footnotetext{
${ }^{5}$ Según Luis Ignacio García (2011: 125), "bulle en la alegoría el 'carácter destructivo' que disuelve la bella apariencia y plantea claves de 'representación' dislocadas (el jeroglífico, el emblema, la cripta, el cadáver, la prostituta), que dan cuenta de lo muerto y del mal, de un mundo carente de redención".

${ }^{6}$ El Ford Falcon era en el vehículo de movilización de las patrullas policiales que llevan a cabo sus 'operativos' de asesinato, secuestro y desaparición. El avión de las fuerzas armadas convoca los 'vuelos de la muerte', en los que los detenidos eran arrojados vivos al Río de la Plata

${ }^{7}$ El Equipo Argentino de Antropología Forense (EAAF) es una organización científica, no gubernamental y sin fines de lucro que aplica las ciencias forenses -principalmente la antropología y arqueología forenses- a la investigación de violaciones a los derechos humanos en el mundo. Se formó en 1984 con el fin de investigar los casos de personas desaparecidas en Argentina durante la última dictadura militar (1976-1983) y desde entonces el equipo trabaja en Latinoamérica, África, Asia y Europa.

${ }^{8}$ La agrupación HIJOS (Hijos e Hijas por la Identidad y la Justicia contra el Olvido y el Silencio) se formó en 1994 como un espacio de lucha y militancia de los hijos de desaparecidos de todo el país. Sus prácticas creativas y lúdicas de protesta se distinguieron desde el comienzo. Dentro de estas prácticas, los escraches señalaban los domicilios de represores que vivían en libertad e impunidad.

${ }^{9}$ He trabajado estas cuestiones en este artículo de la Revista Amerika.
} 
¿Cómo fotografiar a un sobreviviente?

Encontrar el modo de hacerlo es el desafío que se propone la artista. En algunos casos, por ejemplo en los retratos de Nilda Eloy y de otra sobreviviente nombrada sólo con la inicial M., Zout usa un recurso frecuente en su obra: el de la doble exposición.

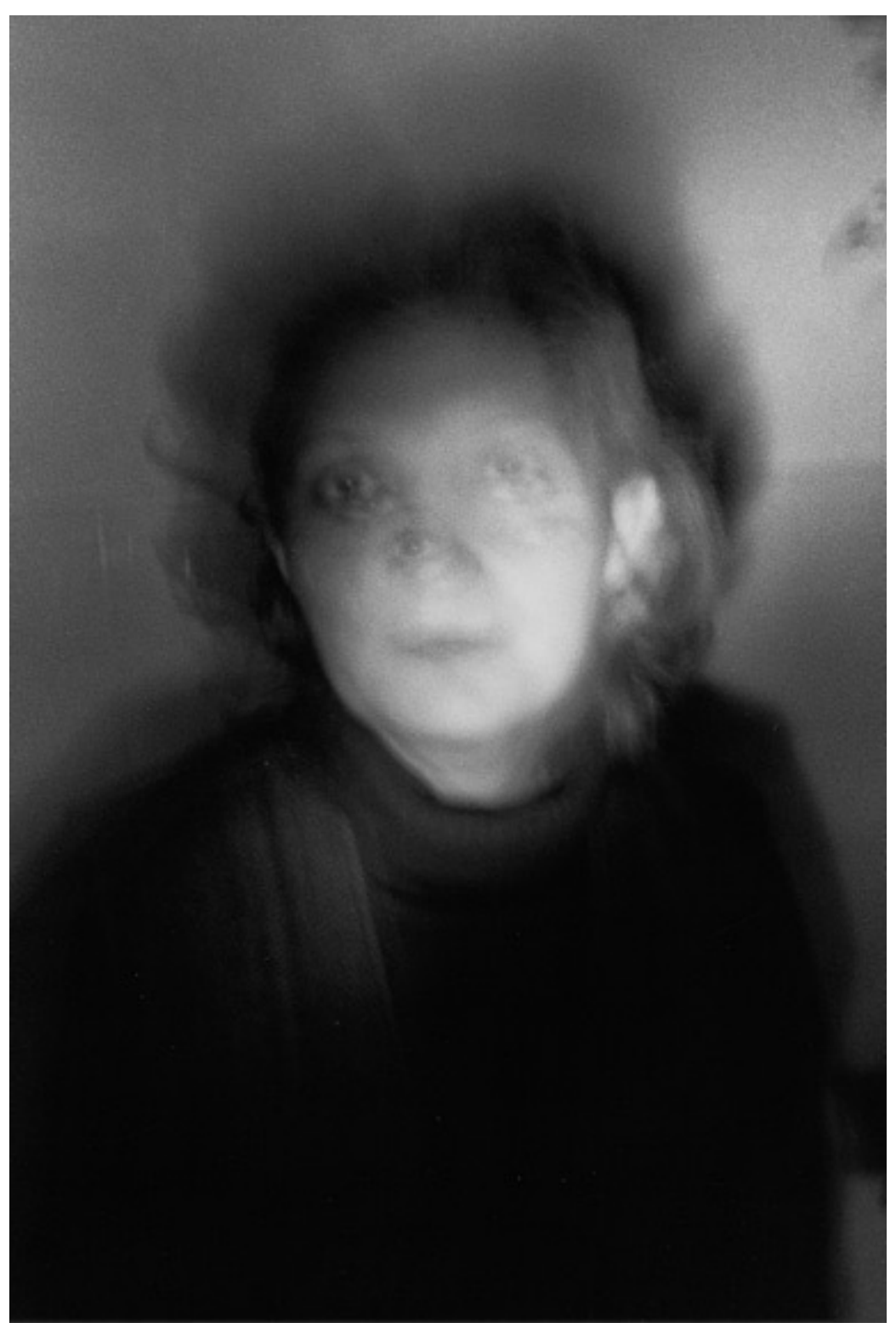

"M, sobreviviente" - Desapariciones, Helen Zout, 2011. 


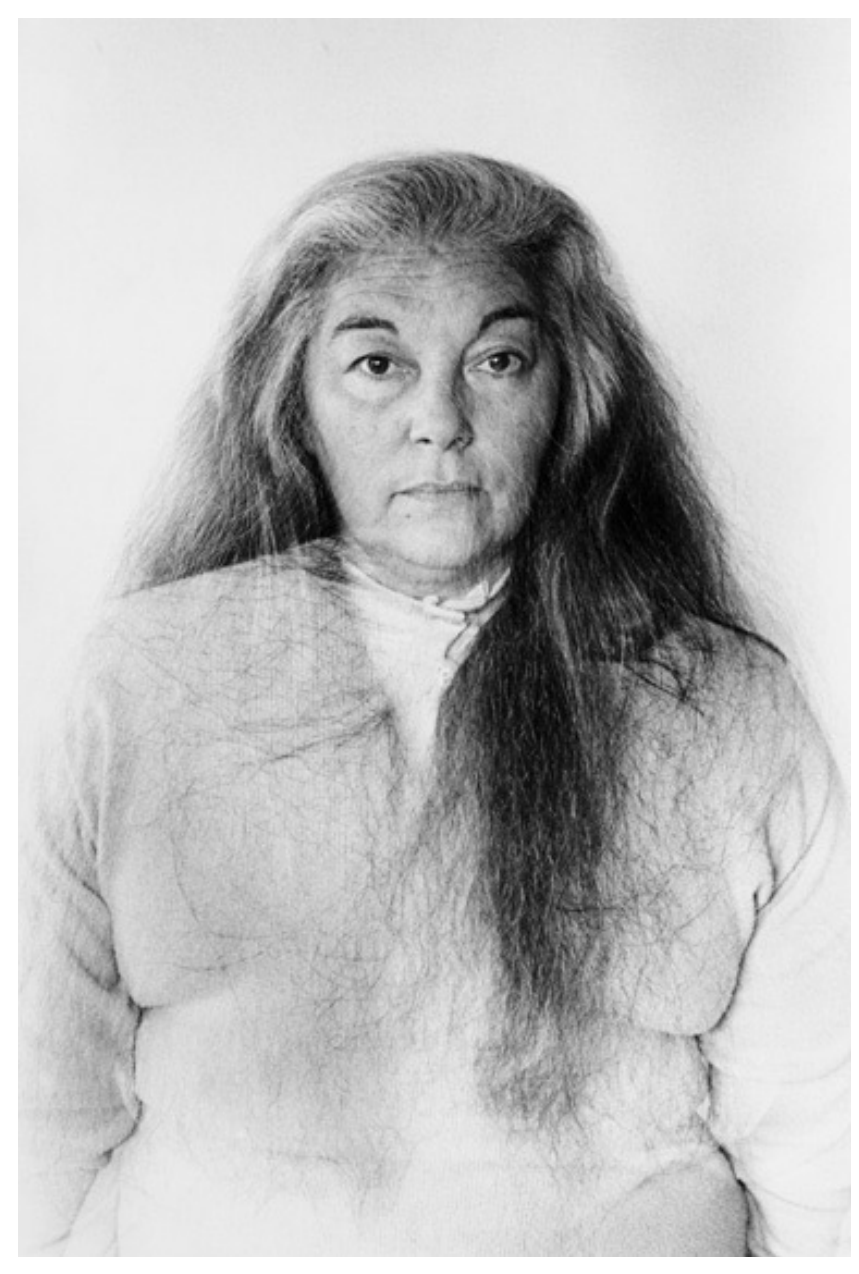

“Nilda, sobreviviente del centro clandestino Arana, La Plata” - Desapariciones, Helen Zout, 2011.

En el caso de M., su cara doblemente expuesta y superpuesta (unos segundos ojos aparecen en sus mejillas) mira a cámara desde el centro iluminado de una foto oscurísima y movida, donde ella está vestida de negro sobre un fondo negro. Como un contrapunto de esta imagen, la foto de Nilda es predominantemente blanca, tanto en el fondo como en la vestimenta de la retratada. En ella, Nilda mira a cámara de frente con el pelo suelto largo y canoso y, aunque en una primera mirada parecería un retrato convencional, pronto se observa cierta rareza. En un segundo momento, se observa que la cara de Nilda también está atravesada, arañada por su propio cabello, ya que Zout hizo una doble exposición del mismo negativo, retratándola de frente y de espaldas a la vez. Así, la textura del cabello se sobreimprime a toda la foto dando un aire extrañado, quizá como las huellas del trauma dan al sobreviviente. 
Natalia Fortuny. Dos veces Julio...

¿Por qué los rostros de estos sobrevivientes no son claros? ¿Por qué no se muestran bien a cámara sino que algún recurso les añade confusión?

Una posible respuesta la encontramos en la reflexión de Judith Butler sobre las fotos de torturas en la cárcel de Abu Ghraib, donde ve en el rostro ensombrecido la difusa huella visual de lo humano. "Los humanos torturados no se conforman fácilmente del todo a una identidad visual, corpórea o socialmente reconocible, sino que su oclusión y obliteración se convierten en el signo continuador de su sufrimiento y de su humanidad" (Butler, 2010: 136). Esta incertidumbre visual es la que Zout elige para hablar de los sobrevivientes y de su sufrimiento permanente. Invocando recursos sencillos -imágenes movidas, morosas o superpuestas- complejiza así el problema representacional de los desaparecidos. ${ }^{10}$

En este plan retrató también a Jorge Julio López, ex detenido-desaparecido y sobreviviente de la dictadura vuelto a desaparecer en el año 2006 tras atestiguar en la causa que condenó, un día después de su desaparición, a Miguel Etchecolatz a reclusión perpetua. Zout presenta dos retratos de López muy similares, uno con los ojos abiertos y otro, el que Orge retomará, con los ojos cerrados. Con el epígrafe “Jorge Julio López, sobreviviente del centro clandestino Arana, La Plata, 2000”, López aparece en primer plano, con el cuello y el principio del pecho desnudos, en gama de grises. En esta célebre imagen, López cierra los ojos dolorosamente, algo desenfocado, y su escaso pelo está electrizado. Este cerrar los ojos que supone no querer ver o no querer recordar - cerrar los ojos a lo inmirable del recuerdo- también produce un quiebre o un ruido en el reconocimiento de la humanidad del retratado, ya que por definición tácita el retrato implica la mirada del fotografiado. Zout ha dicho que a López "lo retraté varias veces pero me quedé con esa foto de los ojos cerrados” debido al gesto de concentración, de recordar y dar testimonio, y que "López se cuidaba un montón con quien hablaba”. El fotógrafo Res piensa que López

\footnotetext{
10 " Hay magia en la imagen movida, en el borroneado. 'Yo tiemblo (eso tiembla), infinito incesante que se estremece' [la cita literaria es de Henri Michaux]. Cuando la foto decide integrar el rastro del movimiento visible, darle su lugar en la toma y la composición, cede a una fuerza ambigua" (Bellour, 2009 : 87). Tal como afirma este teórico francés, las imágenes movidas se atreven a la línea, la profundidad y la duración. La expresividad de estas imágenes tienen que ver con lo que llama "el grado cero de la imagen movida: el estremecimiento” (Bellour, 2009: 91). Este estremecimiento es entre móvil e inmóvil, y pone en escena una dureé, hace al tiempo visible, instala una duración. Por otra parte, si hay tiempo puede haber relato, y en este sentido pareciera que en las imágenes movidas de Zout está efectivamente sucediendo algo. Hay un tiempo atascado y móvil que otorga a estas imágenes incluso un poder de dramatización y ficción. Se sabe que el ojo humano no ve en movimiento y, por eso, la imagen movida bajo su disfraz de transmisora real de una presencia movediza delante de la cámara certifica extrañamente a la foto como invención. Según Bellour, “es una de las maneras más seguras que tiene la fotografía para designarse como artificio, para desearse como arte” (Bellour, 2009: 87), para captar un efecto de lo real, sin tomarlo como realidad. Así, y aunque sean dos recursos claramente diferentes, en su artificiosidad vedada al ojo humano se asemejan la imagen movida -el rastro del movimiento- y lo borroso de lo desenfocado. Y ambos recursos son puestos por Zout en sus fotos para generar un efecto singular de afección.
} 
Natalia Fortuny. Dos veces Julio...

parece a punto de recibir un disparo ${ }^{11}$. Este retrato se ha vuelto emblemático y ha sido usado numerosas veces en Argentina para denunciar el caso de su segunda desaparición aún no esclarecida.

En el libro, las fotos de López aparecen acompañadas y precedidas por otra foto: la de un dibujo realizado él mismo para graficar el accionar de un grupo de tareas de La Plata. Con tremendos dibujos casi infantiles y bajo la leyenda manuscrita "Mujer gorda de V. Elisa”, López retrató a una mujer desnuda atada a un poste siendo torturada por dos hombres encapuchados y supervisados por un jefe, también encapuchado $^{12}$. Aquí la foto es foto y prueba de una prueba judicial -el dibujo- que ha acompañado la declaración de un testigo central. Aparece primero su testimonio, en formato visual -el dibujo-, y después la víctima convertida en víctima doble al desaparecer nueva y definitivamente. Como bien subrayan las imágenes de este libro al presentar dos veces el caso López, esta segunda desaparición ocurre en democracia y en el presente. Así, las fotos no se contentan con mostrar sólo los restos de ese pasado: más bien reconocen e insisten en señalar la parte del horror y de injusticia que aún habita en nuestra sociedad.

Volvamos entonces a la foto de Gabriel Orge que he tomado como disparadora de este texto. Aquí López, doblemente desaparecido, aparece dos veces, duplicado a través de la inserción de una foto icónica en su investidura de testigo-desaparecido en un contexto completamente ajeno y extrañado. La foto original nos es familiar -conocemos su historia, es un triste icono- y eso provoca aún más extrañamiento cuando lo vemos aparecer en medio de la naturaleza. El fondo claro del retrato de Zout se trueca acá en noche oscura, en cielo y escenario de ocaso ${ }^{13}$. Ese cielo sereno en que se recortan por detrás la hilera de árboles, está limpio pero oscuro. Hay una mínima nube que incluso nos hace dudar si forma parte de la cabeza, como un desprendimiento. ¿Cuál es el límite de lo proyectado?

La foto de Orge potencia la foto anterior, la magnifica con su intervención fantasmática-vegetal en esta nueva y singular foto. Algo pasa con el paisaje cuando se instala la imagen y eso se entrevé en el armado visual de la foto final.

López reaparece, López vegetal, López fantasma sin cuerpo, López hundido, López proyectado. Con las venas blancas y la boca ahogada, sumergiéndose.

\footnotetext{
11 Todos los testimonios citados de Helen Zout y también el de RES fueron tomados de la charla-entrevista realizada a Helen Zout el 28 de abril de 2011 con motivo de una visita guiada por su muestra Desapariciones en la FotoGalería del Teatro San Martín, en donde el fotógrafo estaba también presente.

12 En la entrevista, Zout afirmó que "sus dibujos son increíbles: un trazo naïf y a la vez mucha potencia. Todo albañil dibuja. [...] Toda su vida posterior [a su desaparición] fue una reconstrucción de los hechos. Todos sus pasos reconstruían los hechos."

13 Antes de llevar la imagen al aire libre, Orge intervino la fotografía de Zout, llevándola de gama de grises al blanco y negro.
} 
Entonces, ¿López aparece o se hunde? El rostro de López toca y no el agua, la imagen no alcanza una dimensión táctil. La foto corrobora las límitaciones de la imagen en dos dimensiones y expande ese límite para hacer palpable lo que no puede palparse (la imagen, lo desaparecido). López está mutilado y se hunde. Primo Levi llama hundidos a esos prisioneros que son ya 'no hombres', que no tienen pensamiento ni lengua (Primo Levi, 2006; Agamben, 2000).

Por ello, volver a la naturaleza aquí no es signo de armonía sino más bien de pérdida de la condición humana, de nuda vida. López cierra los ojos al nuevo horror, ya no a la memoria dolorosa como en su foto de testigo, sino a la condición nueva de soledad en el paisaje, de pura imagen sin cuerpo a la que está sometido por segunda vez. Y además va perdiéndose como sujeto retratado porque la mirada hace al sujeto humano. Aquel cerrar de ojos de la foto original se agrava acá porque va desapareciendo el retratado, que se hunde en el agua y, más aún, se va a apagar con la luz del día. López cierra los ojos ante esta segunda desaparición, ante este hundimiento que recibe sin resignación. Frente a lo que está ocurriendo, clausura su mirada.

La perspicacia de Zout como retratista queda subrayada en la foto de Orge, entre la vegetación y agua. Un agua que no es laguna ni lago sino río y, aunque pequeño, remite también al Río de la Plata donde se tiraban vivos a los prisioneros en los vuelos de la muerte. Un río que es la figura del paso del tiempo: Heráclito, el reloj clepsidra, el devenir indetenible. Y López "apareciendo" ahí: entre medidas del tiempo y de la contemplación, en el reflejo narciso del agua, en la blancura de la noche, en lo mínimo del gesto re insertado en una situación vital y sin embargo anómala.

Así, la fugacidad y la inmaterialidad de la presencia de López no alcanza para hablar de apariciones. Más bien, el gerundio del título "Apareciendo a López" convoca la idea que Orge se propone al realizar estas fotos: ellas simplemente documentan una proyección efímera. Entiende a esta imagen como un registro de su intervención en el paisaje, de sus intentos fútiles y fugaces de hacer aparecer a López frente a la imposibilidad obvia de la aparición concreta ${ }^{14}$. La instalación precaria y pasajera de la foto de Zout en el agua es la verdadera obra en esta obra.

¿Y por qué en el paisaje natural?

En primer lugar es interesante mencionar que en el mismo año el Salón Nacional de Artes Visuales premió también -con el Gran Premio Adquisición- la serie Flores en la Esma de Gabriel Díaz, un conjunto de imágenes de flores tomadas con polaroids vencidas y, por esto, ligeramente dañadas. Según el propio Díaz, como una metáfora de aquellos que nacieron en la Escuela de Mecánica de la Armada

\footnotetext{
${ }^{14}$ Hay muchas obras de arte-activismo que son efímeras intervenciones acerca de López, tal como describe Ana Longoni $(2009)$.
} 
durante la dictadura: niños hijos de desaparecidos y apropiados ilegalmente por sus captores ${ }^{15}$. Así, es llamativo el hecho de que este año el Salón Nacional premiara en Artes visuales a dos series que tenían por tema a la vez la historia reciente de la dictadura en su relación con la naturaleza.

Por otra parte, no es la primera vez que Orge se ocupa de este tema. Su serie Elpaisaje crítico, de 2012, funciona como antecedente en presentar al paisaje de manera que hable e interpele a quien mira. Allí piensa al territorio como efecto de la acción de una comunidad, con las marcas históricas de, por ejemplo, la producción agrícola actual en el campo o de la crisis global en la ciudad. Orge ha dicho en relación a esto que "el paisaje es el hombre en relación con el espacio" y que "un paisaje apacible esconde algo atrás". Intentando, según él, descifrar "la violencia ejercida sobre la tierra”, de modo de "encontrar belleza en el drama". ${ }^{16}$

Algo de estas intenciones se visualiza en este paisaje con López, donde el retrato irrumpe lo apacible y lo oscurece. De hecho, otra de las fotos de su serie Apareciendo es "Apareciendo la mirada de Andrea López", una imagen también proyectada sobre los árboles esta vez para hacer aparecer a una mujer desaparecida el 10 de febrero de 2004 en Santa Rosa, La Pampa, presuntamente asesinada por su marido, quien la explotaba en una red de trata de mujeres.

Una vez más, ¿por qué en estos paisajes?

Orge llegó a construir estas obras inspirado por el concepto de intemperie y el trabajo de los artistas de los 60 en el espacio público, "que tomaban la calle como un lugar de experimentación”17. Por eso, en su primera intervención proyecta la foto en la ciudad. Pero sin embargo luego se mueve hacia escenarios naturales, y aquí es donde interviene con fuerza su memoria personal y un suceso que lo marcó en la infancia. Las barrancas del río Ctalamochita en la ciudad de Bell Ville no son solamente el lugar de nacimiento de Orge. Según el artista, “esa zona del río es un lugar muy significativo para mí, ahí aprendí a nadar en contra de la corriente estimulado por mi tío Ovidio y a los seis años, en ese mismo

\footnotetext{
${ }^{15}$ Lo técnico en este caso tiene mucho valor para Díaz "porque la Polaroid se extinguió hace algunos años y 'Flores en la ESMA' es la recuperación de un material que ya no existe. De manera sorprendente para mí las películas funcionaron, y siento que la belleza de la imagen atravesó todos esos años de oscuridad. Hay rincones de las fotografías a los que estas iluminación no llegó, por el daño y el paso del tiempo, y eso también interviene en el sentido”. Leer aquí.

${ }^{16}$ Tomado de este texto. En el texto que acompaña la muestra, se lee que este proyecto fotográfico retrata "distintas formas de producción local que han surgido como consecuencia de la crisis global y el sistema capitalista: el desmonte para el cultivo de soja, el trabajo precario, los mecanismos alternativos de supervivencia, la economía paralela y la inmigración. Las fotografías de Orge representan un paisaje en transformación; por un lado explotado, quemado, cercado, y por otro precariamente ocupado por asentamientos provisorios. El paisaje, que implica un sujeto observador y un terreno observado del que se destacan sus cualidades, se revela en este proyecto desde la mirada de Orge como un paisaje en crisis, y además de natural, como un paisaje socio-cultural donde ver las desigualdades económicas y sociales." (Hug y Guevara, 2012). La muestra puede verse en la página web del fotógrafo.

${ }^{17}$ Tomado del siguiente texto.
} 


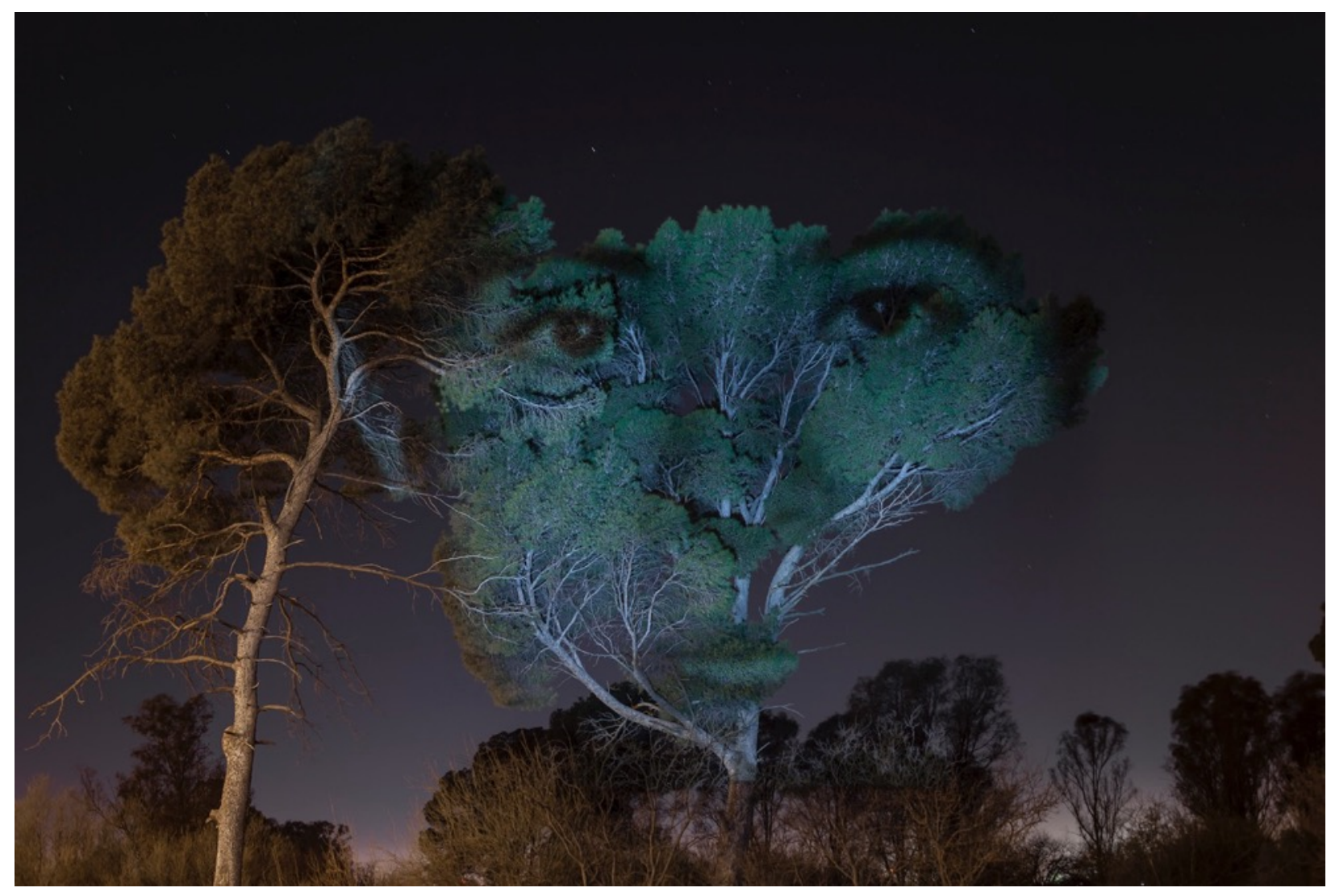

“Apareciendo la mirada de Andrea López” - Gabriel Orge, 2015.

lugar, vi la primera escena de violencia en mi vida." ${ }^{18}$ Es decir, Orge escoge los escenarios naturales por una relación significativa con su propia vida pero fundamentalmente con el inicio de su memoria acerca de los hechos violentos. La naturaleza es elegida aquí como espacio de violencia, como paisaje ligado a la historia y al peligro.

Otras memorias fotográficas de la posdictadura han trabajado también con los espacios de la naturaleza para evocar la violencia represiva y la ausencia de los desaparecidos.

En su serie Imágenes en la memoria (2011), Gerardo Dell’Oro arma un recorrido fotográfico alrededor de la desaparición de su hermana Patricia, que incluye fotos familiares, imágenes de recuerdos escolares y de juventud (boletines, cartas) y una larga serie de retratos de su sobrina Mariana, la hija de

\footnotetext{
${ }^{18}$ Tomado de este texto. Allí también Gabriel Orge ha dicho que, "hasta ahora, la imagen de López (tomada por Helen Zout) apareció en lugares relacionados a mi propia historia, espacios simbólicamente potentes que me permiten construir una metáfora visual".
} 
Patricia y su compañero, que "conoció por fotos a sus padres” ya que al momento de su secuestro tenía 25 días ${ }^{19}$. La tercera y última parte de esta serie/libro se llama “Árboles” y es un ensayo sobre los últimos días de Patricia, asesinada junto a su compañero en el CCD Pozo de Arana un mes después de ser detenidos. La familia se entera de este hecho en 1999 por el testimonio de Julio López, cuando ya llevaba 23 años de incansable y, por momentos, esperanzada búsqueda. Dell’Oro fotografía sin saberlo, "intuitivamente" en sus palabras, los árboles cercanos al último lugar que habitó su hermana, en el mismo año en que se dan los Juicios por la Verdad en La Plata -lo que el fotógrafo entiende como "el marco emocional” de estas imágenes-. Estas fotos muestran árboles y escenarios nocturnos llenos de vegetación, tomados temblorosa y morosamente. La falta de luz hace que el tiempo fluya con movimiento en las imágenes.

Es de noche, y la luz viene de un siempre imperfecto flash, o de los faros de un auto, o del sol quebrando el horizonte apenas. Sobre estas imágenes que son también de furia, Dell’Oro sostuvo que "la idea de incluirlas tiene que ver con los altibajos en la búsqueda de justicia, la esperanza y la derrota. Algunas son oscuras y movidas, otras tienen formas de tumbas, de siluetas y hasta de un puño en alto" (Meyer, 2008).

Los árboles, también presentes en algunas fotos de Zout y por supuesto en la foto de Orge, son también la dramática constatación de la continuidad de la vida, aún allí donde el horror aconteció. Ellos encarnan el tiempo e incluso podrían encarnar el olvido. Griselda Pollock se refiere a esto:

Pensando en el genocidio nazi, el artista holandés Armando acusaba a los paisajes donde ocurrió. Eran paisajes culpables. Ernst van Alphen descarta toda sugerencia de que los

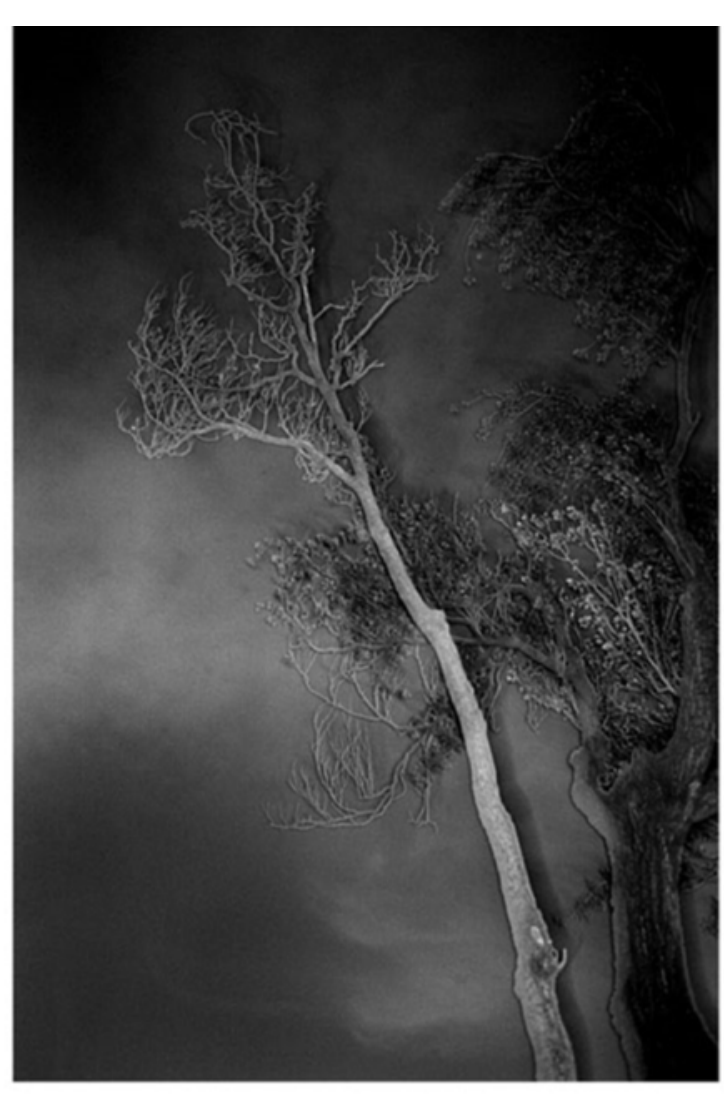

Imágenes en la memoria. Gerardo DEll’Oro, 2011.

\footnotetext{
19 Dell'Oro refiere allí la inexistencia de fotos de Patricia con su beba, “seguramente estaban sin revelar, en la Rollei que también se llevaron quienes los secuestraron”.
} 


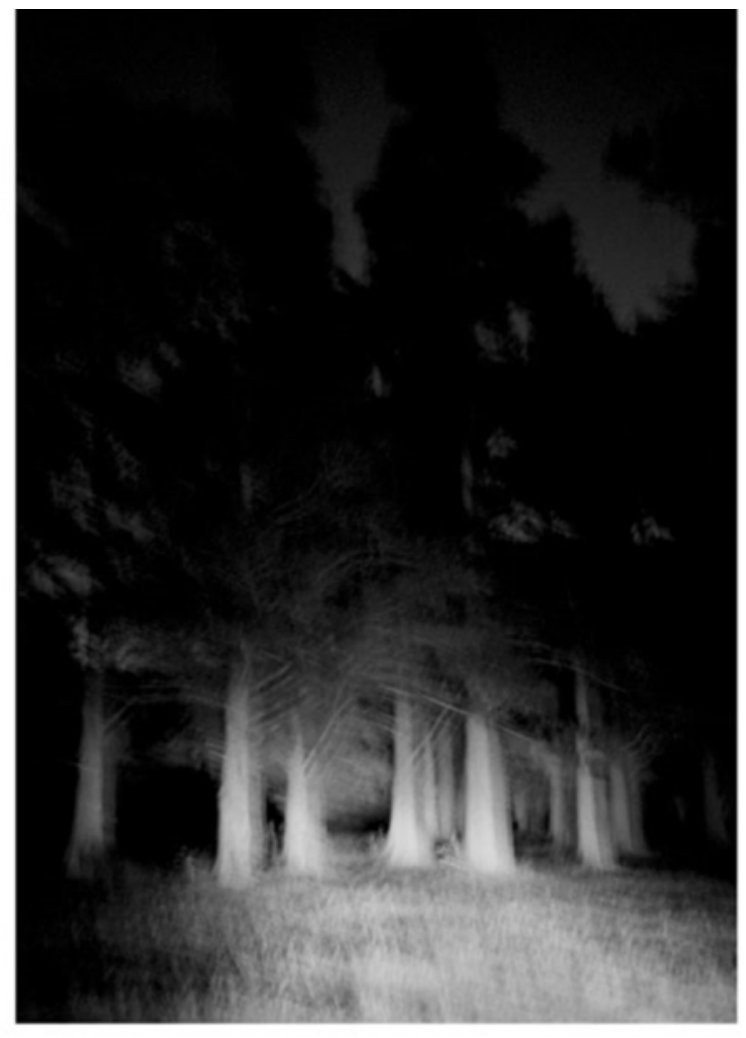

Imágenes en la memoria. Gerardo DEll’Oro, 2011. árboles acusados por Armando sean metáforas de los genocidas. Más bien, los árboles se transforman en huellas indiciales de la violencia que sucedió ante ellos; pero se trata de testigos indiferentes. Más aún, su indiferencia (siguen creciendo, incluso ante lo que han 'visto'), sugiere que con el tiempo encubrirán las huellas. Los árboles encarnan el tiempo, que trabajará sin descanso a favor del olvido (Pollock, 2008: 116),

Dell'Oro da cuenta del terror al explorar visualmente estos escenarios siniestros e intercalarlos con el testimonio de López sobre las torturas infligidas a su hermana y cuñado, y el asesinato de ambos. Después de estas fotos de la huella del horror en la intemperie, Dell'Oro fotografía -ahora con claridad- lo que parece una carpeta de expediente, y luego dos manuscritos con dibujos y anotaciones hechos por Jorge Julio López, compañero de militancia desaparecido en el mismo CCD y que narró en calidad de testigo el asesinato de Patricia y su pareja. El testimonio del padre de Patricia y también el testimonio de López acompañan este conjunto de fotos. Dell'Oro cree que Julio López, al llevar a su familia el mensaje de amor a su hija que Patricia le había dado horas antes de morir, le "dio la foto que me faltaba, una imagen relatada que estaba en su memoria" (Meyer, 2008). Este motivo de la foto que falta es posiblemente el impulso principal de todos los artistas familiares de desaparecidos, atravesados no sólo por la ausencia del desaparecido sino por el hueco en el álbum que esa ausencia ha provocado -en este caso, la falta de la foto de Patricia con su hija-. Una pintura en acrílico hecha por Patricia, un retrato de Mariana y un retrato de López cierran la exposición de Dell'Oro, cuyo último texto está dedicado a recordar que López continúa desaparecido.

Dell'oro ha conformado también la serie 100 fotos por López que resulta un interesante registro en un centenar de imágenes de diversas apariciones simbólicas de la figura de López, subrayando la actualidad del reclamo de aparición con vida y dando cuenta a la vez distintas manifestaciones artísticas alrededor de esta doble desaparición (incluyendo dos retratos de López hechos por Dell'oro previos al 


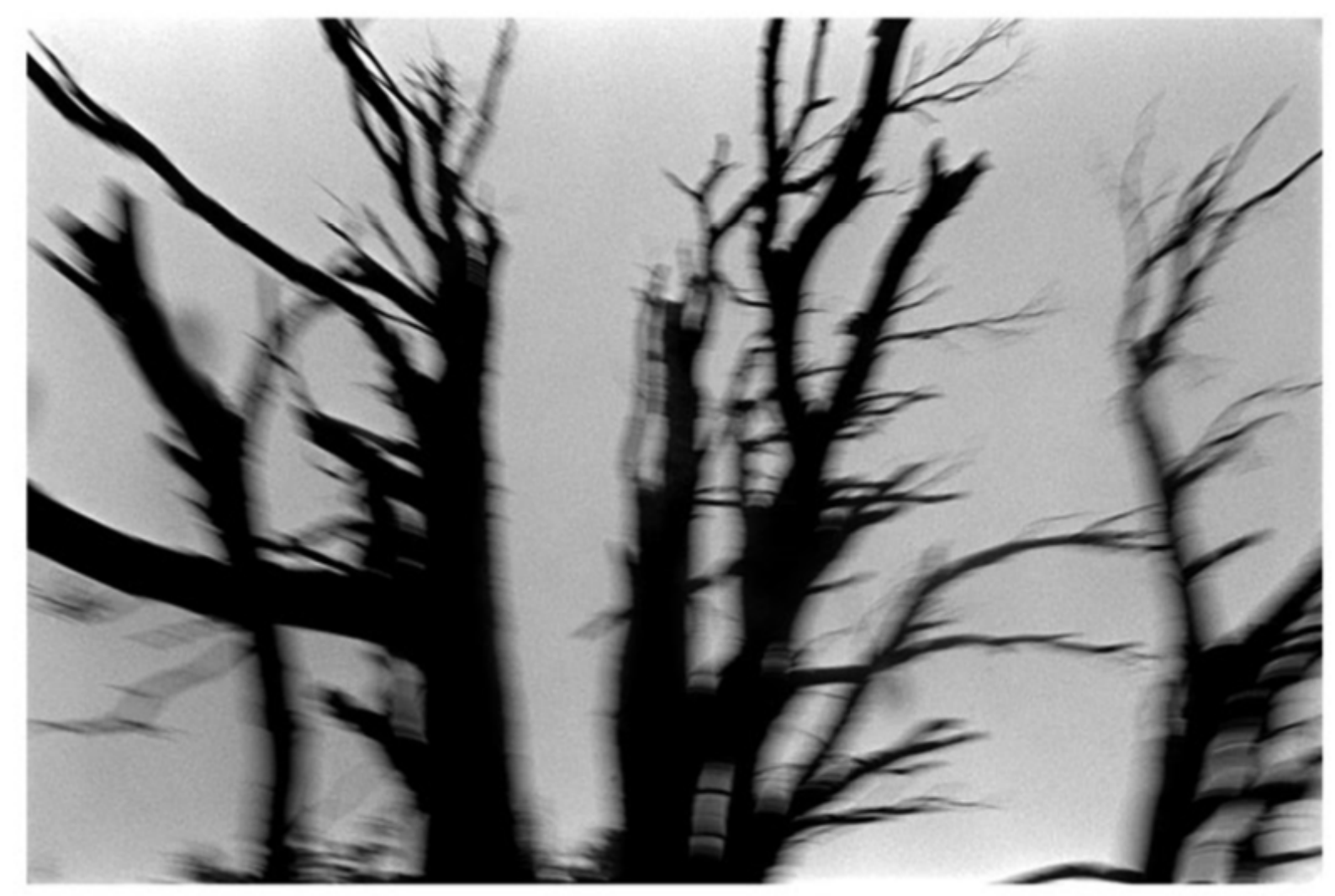

Imágenes en la memoria. Gerardo DEll’Oro, 2011.

secuestro, así como también obras de artistas como Hugo Vidal y Lucas DiPasquale $)^{20}$. Por otra parte, la serie presenta una imagen que da cuenta de que el 11 de octubre de 2011 en el juicio oral llamado "Circuito Camps" se proyectó con carácter de testimonio el video de la declaración que Jorge Julio Lopez había dado en el anterior juicio de 2006. Fue la primera vez en un juicio por delitos de la dictadura que un testigo declaró estando él mismo desaparecido. Los dichos de López dieron testimonio, entre otras cuestiones, de la desaparición y asesinato de la hermana de Dell' Oro junto a su compañero en el Centro Clandestino de Detención conocido como Pozo de Arana

Otra serie que trabaja la naturaleza en relación con la historia reciente es La Memoria del Paisaje (2010) del chileno Gastón Salas. Se trata de dípticos cuya mitad izquierda muestra fotos de paisajes Chile, al estilo clásico del paisajismo, y cuya parte derecha cuentan, en castellano y en inglés, los sucesos represivos ocurridos en ese sitio, en general asesinatos de campesinos y/o hallazgos de cadáveres o

${ }^{20}$ La serie está disponible en esta web. 
restos óseos ${ }^{21}$. Las fotos muestran, siempre en plano general y abierto, montañas, cielos imponentes, ríos, lagos y caminos que se pierden en el horizonte. La mirada hacia el paisaje es la misma que se puede encontrar en los libros que publicitan las bellezas de un país: bucólicas y perfectas a nivel técnico -es decir, no experimentan con cuestiones de foco, movimiento o tiempos de toma, son 'objetivamente bellas'-. Parecen prometer una tierra de encantos en todos los climas. Sin embargo, a continuación ocurre la obligada lectura del texto de la derecha, donde se informa las fechas y los nombres de quienes han sido asesinados en ese sitio, se narra de qué manera fueron muertos y cómo han sido encontrados sus cadáveres o sus restos - días, años o décadas más tarde-. A la oposición entre imagen y palabra, entre esos dos lenguajes inconmensurables yuxtapuestos, se agrega aquí la contradicción entre lo sublime de esos paisajes y la memoria del horror que soportan. La lectura del texto inevitablemente modifica la segunda mirada al paisaje, donde las huellas parecen haberse borrado con el viento o con el agua. Las palabras quiebran la mudez de los lugares naturales, intentando romper asimismo el silencio de la sociedad chilena. Salas documenta aquello que no quedó en la (des)memoria de estos paisajes, aquello que sólo la palabra y el recuerdo de los familiares y sobrevivientes pueden traer desde el olvido. El artista habla así de esta serie: "En los paisajes de Chile se percibe una sobrecogedora carga oculta, se advierte una misteriosa sensación de olvido y una inquietante tranquilidad, que hace que la mirada, sostenga la tensión de lo que se contempla. (...) El paisaje natural, que tradicionalmente contiene las ideas de lo sublime y lo hermoso se confronta en este trayecto con la violencia de los sucesos. Así, en una misma imagen se cruza, la belleza, el silencio y la calma con la crueldad de la masacre y la monstruosa brutalidad de la muerte. ${ }^{22}$

Como si se tratara de dos páginas que describen dos veces el mismo paisaje pero con un corrimiento, el espectador puede preguntarse, toda vez que se ha modificado su mirada al leer el texto: ¿cambió algo en el paisaje? ¿Se modificó la foto al volver a mirarla luego de la lectura del texto?

\footnotetext{
${ }^{21}$ El fotógrafo recorrió el país de norte a sur, investigando archivos y entrevistándose con funcionarios, miembros de organizaciones de DDHH y familiares de las víctimas.

22 Texto de la presentación de la muestra cuando fue expuesta en la Foto Galería Arcos. Tomado del sitio online de la galería.
} 

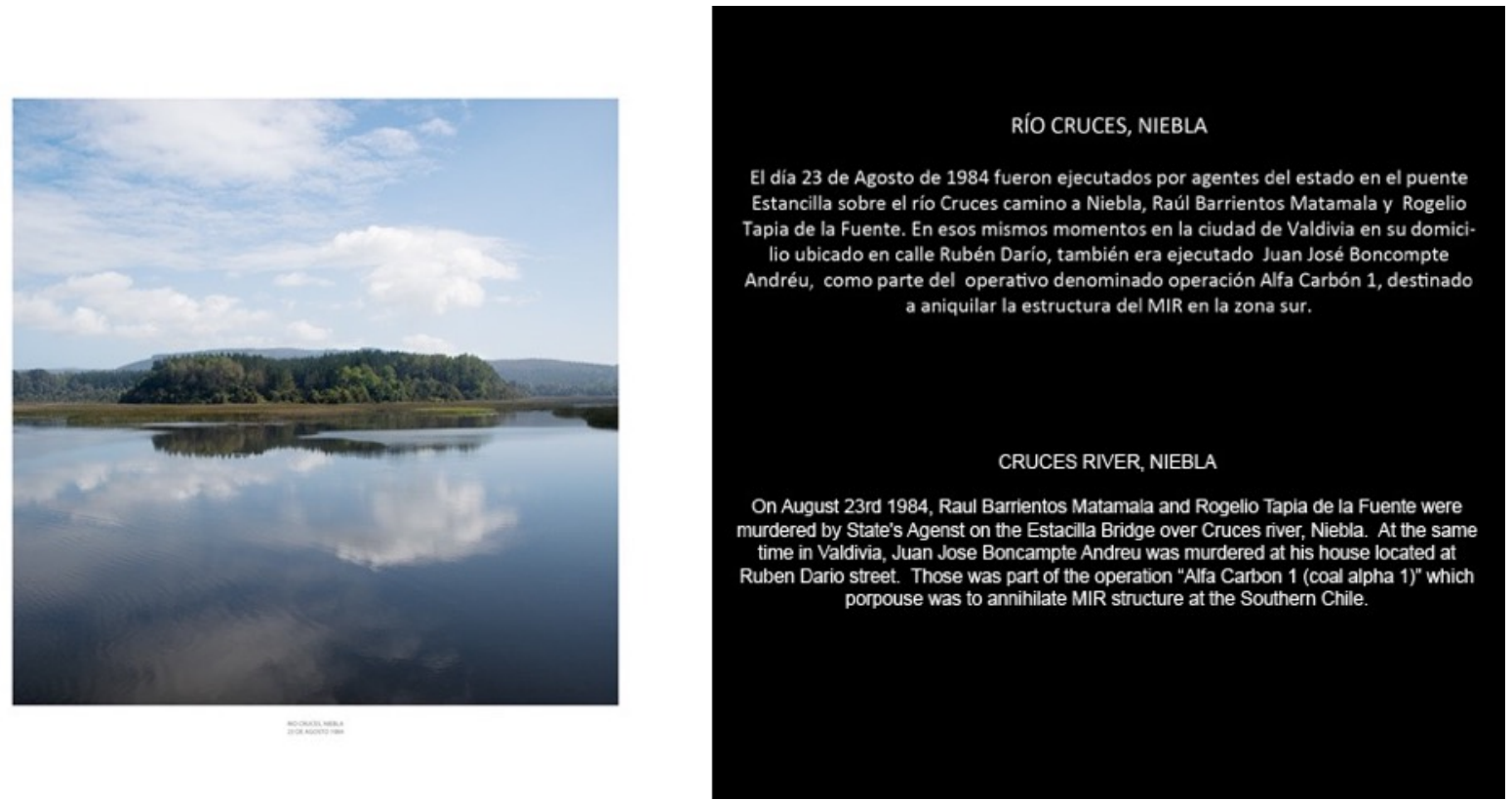

'Río Cruces, Niebla', de La memoria del paisaje - Gastón Salas, 2010.

\section{La memoria y su doble}

En su erudito libro sobre las representaciones de las masacres a lo largo de la historia, Burucúa y Kwiatkowski (2014) abordan el concepto warburgiano de Denkraum: un espacio de distancia y de conocimiento entre el ser y su objeto. Muchas obras fotográficas contemporáneas, en lugar de trabajar en pos de una mimesis, se orientan más bien por el camino largo de la distancia -como Sebald hace en su novela Austerlitz al alejar todo el tiempo la voz del narrador-. Burucúa y Kwiatkowski arriesgan que la "fórmulas de representación" de las masacres de esta época tendrán que ver con el doble, con el Doppelgänger en forma de siluetas, máscaras, réplicas, fantasmas, sombras. En fin, será la duplicación lo que defina a la representación de la masacre en el siglo XX, incluidas la represión y las desapariciones de la última dictadura de nuestro país. Son juegos que tienen que ver con la construcción misma de identidades dobles, como en esta foto de Orge y también como en las fotos de sobrevivientes de Zout.

Escapando a aquello de que la repetición es repetición del trauma, las obras fotográficas que ponen en marcha esta fórmula en el caso argentino optan por la distancia, el rodeo del artefacto, de lo construido y la doble exposición. Porque quizá sea necesaria la inexactitud de esos dobles para no quedar atrapados por el trauma y poder decir (mostrar) algo.

Al igual que la silueta como doble tiene ventaja para hablar del pasado por su cualidad de índice y su contigüidad con el cuerpo humano copiado, la fotografía ha sido elegida numerosas veces para evocar 
la dictadura -fotografía que es también índice y cuyo antepasado es, claro, aquella silueta-. Todas las fotos y en particular esta foto operan también la transformación de sujetos en objetos, al decir de Christian Boltanski -quien cree además que la ropa, la fotografía y el cuerpo muerto comparten una característica: ya no hay nadie allí- 23 .

Las memorias fotográficas producidas en la posdictadura argentina son además ya dobles por su calidad de artefactos construidos a la vez que indiciales en tanto propiamente fotográficos. Esta obra de Orge, de factura arcimbóldica, se instala en la herencia del retrato del desaparecido (desde aquellos primeros reclamos de las Madres de Plaza de Mayo con pancartas con las imágenes de sus hijos) y también en la serie de aquellas obras que utilizan las proyecciones de los retratos familiares para convocar la memoria de sus desaparecidos (Lucila Quieto, Verónica Maggi). De esta manera, la obra emplaza un gesto de memoria acerca de López, ex detenido desaparecido que vuelve a desaparecer precisamente tras dar testimonio en un juicio. Porque el testimonio es también lo que puede poner en peligro y no sólo lo que salva o ayuda a los sujetos a salir del trauma-. Esta foto dual, justamente, revela algunas de las duplicidades que continúan rodeando la desaparición de Jorge Julio López. Y así da testimonio.

${ }^{23}$ Boltanski aseveró: "Yo uso fotos porque estoy muy interesado en la relación sujeto-objeto. Una foto es un objeto, y su relación con el sujeto se ha perdido. Tiene también una relación con la muerte" ["I use photos because I'm very interested in the subject-object relationship. A photo is an object, and its relationship with the subject is lost. It also has a relationship with death"] (Semin y otros, 1999: 25, traducción propia). 
Natalia Fortuny. Dos veces Julio...

\section{Bibliografía}

Agamben, Giorgio (2000). Lo que queda de Auschwitz. El archivo y el testigo. Homo sacer III. Valencia: Pre-textos.

Bellour, Raymond (2009). Entre imágenes. Foto. Cine. Video. Buenos Aires: Colihue

Burucúa, José Emilio y Nicolás Kwiatkowski(2014). "Cómo sucedieron estas cosas". Representar masacres y genocidios. Buenos Aires: Katz Editores.

Butler, Judith (2010). Marcos de guerra. Las vidas lloradas. Buenos Aires, Paidós.

Dell’Oro, Gerardo (2011). Imágenes en la memoria, Buenos Aires: La Luminosa.

Fortuny, Natalia (2014). Memorias fotográficas. Imagen y dictadura en la fotografía argentina contemporánea, Buenos Aires: La Luminosa.

García, Luis Ignacio (2011). Políticas de la memoria y de la imagen. Ensayos sobre una actualidad político-cultural. Santiago: Universidad de Chile.

Hug, Alfons y Paz Guevara (2012). Catálogo de la muestra Poetas en Tiempos de Escasez. Museo Caraffa: Córdoba.

Levi, Primo (2006). Trilogía de Auschwitz. México: Océano.

Longoni, Ana (2007). Traiciones. La figura del traidor en los relatos acerca de los sobrevivientes de la represión. Buenos Aires: Norma.

Longoni, Ana. "Activismo artístico en la última década en Argentina: algunas acciones en torno a la segunda desaparición de Jorge Julio López”. Revista de Artes Visuales Errata 0 (2009).

Meyer, Adriana (2008). "La memoria de las imágenes”. Página/12, (28/04/2008). Buenos Aires.

Pollock, Griselda (2008). "Sin olvidar África: Dialécticas de atender/desatender, de ver/negar, de saber/entender en posición del espectador ante la obra de Alfredo Jaar”. En Didi-Huberman, Pollock, Rancière, Schweizer y Valdés: Alfredo Jaar. La política de las imágenes. Santiago: Ediciones Metales Pesados.

Semin, Didier, Tamar Garb y Donald Kuspit (1999). Christian Boltanski. Londres: Phaidon.

Zout, Helen (2009). Desapariciones. Buenos Aires: Dilan Editores. 